\title{
Perfect-Substitutes, Best-Shot, and Weakest-Link Contests between Groups
}

\author{
Roman M. Sheremeta * \\ George L. Argyros School of Business and Economics, Chapman University \\ One University Drive, Orange, CA 92868, U.S.A.
}

August, 2010

\begin{abstract}
This experiment investigates contests between groups. Each group has one strong player, with a higher valuation for the prize, and two weak players, with lower valuations. In contests where individual efforts are perfect substitutes, all players expend significantly higher efforts than predicted by theory. In best-shot contests, where group performance depends on the best performer, most of the effort is expended by strong players while weak players free-ride. In weakest-link contests, where group performance depends on the worst performer, there is almost no free-riding and all players expend similar positive efforts conforming to the group Pareto dominant equilibrium.
\end{abstract}

JEL Classifications: C71, C72, C91, C92, D72, H41

Keywords: contest, between-group competition, within-group competition, asymmetry, coordination, free-riding, experiments

E-mail: sheremet@chapman.edu

* I am particularly grateful to Tim Cason for excellent guidance and support. I thank Jason Abrevaya, Marco Casari, Subhasish Chowdhury, Dan Kovenock, Dongryul Lee, Michael Raith, Anya Savikhin, Jingjing Zhang, anonymous referees, seminar participants at Chapman University, Copenhagen Business School, Maastricht University, Purdue University, University of Arkansas, University of Massachusetts, University of Michigan, and participants at the 2008 Economic Science Association and the 2009 International Industrial Organization meetings for helpful comments. This research has been supported by National Science Foundation Grant (SES-0751081). Any remaining errors are mine. 


\section{Introduction}

Many economic allocations are decided by contests in which individuals or groups expend costly resources while competing to win a specific prize. Examples include corporate competitions between consortia, R\&D and patent competitions between firms and election campaigns by political parties. Most of these contests are characterized by the fact that competition is between groups (e.g. boards of directors, teams of researchers, or committees), and not individuals.

As group contests unfold, conflicts arise within each group and between groups. Members of the same group have incentives to cooperate with each other by contributing individual efforts in order to win a contest. Since effort is costly, each member also has an incentive to abstain from contributing any effort and instead free-ride on the efforts of other members. The amount of free-riding that occurs within a group depends on the composition of the group and the rules that regulate the competition. Members of the same group who have less interest in winning the contest are more likely to free-ride on the efforts of members who have greater interest in winning. However, free-riding behavior is unlikely when the performance of the entire group depends crucially on the performance of each member of a group. We can gain valuable insights into what factors determine the outcome of the competition by studying different group compositions and different contest rules.

Take, for example, a contest between two asymmetric groups: a "Good Manager" group with a highly motivated manager but poorly motivated workers and a "Bad Manager" group with a poorly motivated manager but highly motivated workers. Which group will win the contest, the group with the better motivated manager or the group with the better motivated workers? What is the optimal compensation scheme that motivates the highest performance of each group? How 
do the rules of the competition affect the effort expenditures and the amount of free-riding within each group?

To answer these questions we design a novel experiment in which two symmetric (or asymmetric) groups compete in a contest. Each group has three heterogeneous players - one strong player and two weak players. To avoid confusion, we use homogeneous or heterogeneous to describe within group composition; and symmetric or asymmetric to describe differences between competing groups. So, the fact that each group always has two types of players implies that groups in our experiment always consist of heterogeneous players. The one strong player values the prize more highly than the two weak players and the valuations are common knowledge. The assumptions of the model allow us to interpret the heterogeneity in valuations as heterogeneity in abilities or heterogeneity in costs. All players within each group simultaneously and independently expend their efforts. The group performance is defined as a function of all individual efforts. In the public goods literature, the three most frequently used functional rules are perfect-substitutes, best-shot, and weakest-link (Hirshleifer, 1983; Cornes, 1993). The novelty of our study is that we apply these rules to the contest setting. In the "perfect-substitutes" contest, the performance of a group depends on the sum of individual efforts. In the "best-shot" contest, the performance of a group depends on the best performer. In the "weakest-link" contest, the performance of a group depends on the worst performer. Each group's probability of winning the prize depends on its performance relative to the total performance by both groups. Therefore, the better performing group is more likely to win. However, the group that does not perform well still has some chance to receive the prize.

Contrary to theoretical predictions, we find significant over-contribution of efforts by both strong and weak players in contests where individual efforts are perfect substitutes. This 
over-contribution cannot be explained neither by risk-aversion not by inequality-aversion, but it can be partially explained by social identity theory. Consistent with theoretical predictions, in best-shot contests most of the effort is expended by strong players while weak players free-ride. In weakest-link contests all players expend similar positive efforts conforming to the group Pareto dominant equilibrium. In the contest between two asymmetric groups, as in the "Good Manager" versus "Bad Manager" example, the outcome of the competition depends on the contest rules. The "Good Manager" group with a better motivated manager is more likely to win the contest if the performance of both groups depends solely on the best performer within each group. On the contrary, the "Bad Manager" group is more likely to win the weakest-link and the perfect-substitutes contests. A potential application of these findings is to the managerial economics literature. Our findings suggest that in most of the cases it is not optimal to allocate a very large bonus to the manager if the objective is to achieve the highest performance of a firm. Instead, more equal allocation of bonuses may lead to higher performance of firms.

\section{Literature Review}

The most commonly used contest in the literature is the one proposed by Tullock (1980). In this contest, individual players expend costly efforts to influence the probability of winning a prize. The player's probability of winning is proportional to the player's relative expenditure. Thus, the player expending the highest effort has a higher probability of winning the prize.

The Tullock model considers competing individuals and thus reflects the conflict between individual players only. The first attempts to address inter-group conflict as well as intra-group conflict were made by Palfrey and Rosenthal (1983) and Katz et al. (1990). The pioneering study by Katz et al. (1990), which is built on the original Tullock contest, 
demonstrates that the effort expended by a group depends on individual valuations of the prize and not on the size of the group. One interpretation of this finding is that, as the size of a group increases, the amount of free-riding within the larger group increases to such an extent that the larger group has no advantage over the smaller group (Olson, 1965; Konrad, 2009). Baik (1993, 2008) refined the analysis of Katz et al. (1990) by considering intra-group heterogeneity. He showed that if the group members differ in their valuations of the prize, only the member with the highest valuation expends positive effort. ${ }^{1}$ Other members of the same group choose to freeride on the effort of the member with the highest valuation. Lee (2009) showed that when a group's probability of winning the contest depends only on the player who expends the lowest effort then multiple equilibria exist in which there is no free-riding.

The efforts expended in such contests are difficult to measure in the field since one can observe only the performance which is a function of effort, ability, and random noise (Ericsson and Charness, 1994). With this in mind, researchers have turned to experimental tests of various contests. The first attempts to examine individual behavior in contests using laboratory methods were made by Millner and Pratt $(1989,1991)$. These studies, and many replications, employ individuals instead of groups. ${ }^{2}$ The exception to this is found in experimental studies of political voting models where, instead of individuals, groups are competing for the prize (Rapoport and Bornstein, 1987; Schram and Sonnemans, 1996). A major restriction of political models is that

\footnotetext{
${ }^{1}$ The result that the equilibrium effort levels depend exclusively on the highest valuation for the prize in each group and not on the group size is well known in the literature. This result is also robust to different specifications of contest success function (Nti, 1998; Baik et al., 2001). Several studies suggested using convex cost of effort or modified utility function in order to overcome free-riding and make group size meaningful. For example, Riaz et al. (1995) show that by modifying utility function the total effort expended by both groups increases if either group increases in size. In such case free riding exists within a group, but it is incomplete. Esteban and Ray (2001) show that in case of convex costs the group size is an important factor which influences the outcome of the contest.

${ }^{2}$ Laboratory studies of contests between individuals conclude: there is significant over-dissipation of rent (Millner and Pratt, 1989); all-pay auctions generate higher efforts than lottery contests (Davis and Reilly, 1998; Potters et al., 1998); risk-aversion and quantal response equilibrium can account for some non-equilibrium behavior (Miller and Pratt, 1991; Sheremeta, 2010a); the non-monetary utility of winning is an important factor to explain overdissipation in contests (Sheremeta, 2010b).
} 
the subject's choice space limited to a binary decision: whether to cast a vote or not. The experimental studies on group contest where subjects can make their decisions on continuous space have been recently conducted by Nalbantian and Schotter (1997), Gunnthorsdottir and Rapoport (2006), Sutter and Strassmair (2009), Abbink et al. (2010), Ahn et al. (2010), and Kugler et al. (2010). All of these studies, however, employ perfect-substitutes contests (i.e., the performance of a group depends on the sum of individual efforts) and homogenous players (i.e., all players within the same group are identical). Our experimental design differs substantially by the fact that we have heterogeneous players, instead of homogeneous players. Moreover, we study the impact of three different contest rules (i.e., perfect-substitutes, best-shot, and weakestlink) on the effort expenditures and the amount of free-riding within each group. These are important questions to investigate, given that the majority of contests in reality are between groups with heterogeneous players, efforts of which are not necessarily aggregated by the perfect-substitutes technology.

\section{The Experimental Environment}

\subsection{The Model}

To simplify analysis we assume that there are two groups expending costly efforts in order to win a contest. Group $G$ consists of $N_{G}$ risk-neutral players, and each player $i$ expends individual effort $x_{i G}$. Group $B$ is defined in a similar way. All players simultaneously and independently expend irreversible efforts. The group performance $X_{G}$ is a function of all individual efforts. The three functional forms considered in this study are perfect-substitutes, best-shot, and weakest-link (Hirshleifer, 1983). 
In the perfect-substitutes contest the group performance is a sum of all individual efforts, $X_{G}=\sum_{i=1}^{N_{G}} x_{i G}$. This type of contest resembles many real life competitions where the performance of the group depends on the joint effort of all members within that group. Consider, for example, a contest between two towns for a county's road construction budget. The government of the county selects the winning town based on the lobbying efforts by the people within each town. In such a contest, the performance of a town depends on the sum of all individual lobbying efforts.

In the best-shot contest the group performance depends only on the best performer within a group, $X_{G}=\max \left\{x_{1 G}, \ldots, x_{N_{G} G}\right\}$. An example of such a contest is a competition between groups where each member of each group presents a design of a new product and the group whose member presents the best design receives a reward. In this contest the performance of a group depends only on the best performer within that group.

In the weakest-link contest the performance of the entire group depends on the worst performer within a group, $X_{G}=\min \left\{x_{1 G}, \ldots, x_{N_{G} G}\right\}$. An example of a weakest-link contest is a competition between groups where each member of a group is responsible for a specific task. If any of the members fails to perform the task then the group loses the competition. Other weakest-link, best-shot, and perfect-substitutes examples can be found in Hirshleifer (1983), Bliss and Nalebuff (1984), and Harrison and Hirshleifer (1989).

The performance of each group determines the probability of winning the contest. After all players of group $G$ and group $B$ choose their efforts, $X_{G}$ and $X_{B}$ are compared. The better performing group has a higher chance of winning the prize. The probability of group $G$ winning the prize is defined by a lottery contest success function:

$$
p_{G}\left(X_{G}, X_{B}\right)=X_{G} /\left(X_{G}+X_{B}\right)
$$


That is, each group's probability of winning depends on its performance relative to the total performance by both groups. Our reason for choosing this specific contest success function is that it is simple enough for subjects to understand, but this simplicity does not affect the comparative statics predictions of the theory (Baik, 1993, 2008; Baik et al., 2001; Nti, 1998; Lee, 2009). The lottery contest success function is also commonly used in most of the Tullock contest literature, including virtually all of the experimental contest literature.

In the case where group $G$ wins the prize, player $i$ receives the valuation of $v_{i G}$. All prize valuations are common knowledge and may differ from player to player. Without loss of generality, assume that $v_{1 G}>v_{2 G} \geq \cdots \geq v_{N_{G} G}>0$ and $v_{1 B}>v_{2 B} \geq \cdots \geq v_{N_{B} B}>0$. We will call players $1 G$ and $1 B$ "strong players" and other players "weak players". Given (1), the expected payoff for player $i$ in group $G$ can be written as:

$$
\pi_{i G}\left(x_{i G}, X_{G}, X_{B}\right)=p_{G}\left(X_{G}, X_{B}\right) v_{i G}-x_{i G} .
$$

The first term of the expected payoff, $p_{G}\left(X_{G}, X_{B}\right) v_{i G}$, is simply the probability of group $G$ winning the prize times player $i$ 's valuation of the prize. By expending a higher effort, $x_{i G}$, player $i$ can increase the probability $p_{G}\left(X_{G}, X_{B}\right)$ of winning the contest. Therefore, player $i$ has an incentive to cooperate with other members of his group; but since cooperation is costly, $\left(-x_{i G}\right)$, there is also an incentive to free-ride. It is important to emphasize that, because of the lottery contest success function and the linear costs, heterogeneity in valuations can also be interpreted as heterogeneity in abilities or heterogeneity in costs. For example, without changing the nature of the current contest one could divide (2) by $v_{i G}$ and thus transform this contest into a contest where players have heterogeneous costs.

Theoretical implications of the model described in this section depend on the contest rule. In the perfect-substitutes contest, the pure-strategy Nash equilibrium is unique and is 
characterized by player $1 G$ 's and $1 B$ 's optimal efforts of $x_{1 G}^{*}=v_{1 G}^{2} v_{1 B} /\left(v_{1 G}+v_{1 B}\right)^{2}$ and $x_{1 B}^{*}=v_{1 G} v_{1 B}^{2} /\left(v_{1 G}+v_{1 B}\right)^{2}$. All other players free-ride in the equilibrium and expend no effort. The full derivation of these results can be found in Baik $(1993,2008)$. The intuition behind the equilibrium is that the strong player obtains the highest marginal payoff, whereas all players have the same constant marginal cost. Given this, at the equilibrium effort of the strong player, the marginal payoff for the weak players is always lower than the marginal cost. Therefore, the weak players have no incentive to expend any positive effort. ${ }^{3}$

In the best-shot contest, in addition to the equilibrium of the perfect-substitutes contest, multiple equilibria can arise in which any two players, each from a different group, compete against each other as in a simple two-player contest, while the other players fully free-ride (Chowdhury et al., 2010). This multiplicity of equilibria arises when the valuations of strong players, $v_{1 G}$ and $v_{1 B}$, are not sufficiently higher than the valuations of weak players. In this case, strong players can free-ride on the efforts of weak players. In the next section we will discuss all possible equilibria in the best-shot contest used in our experiment.

The equilibrium of the weakest-link contest has recently been characterized by Lee (2009). In such a contest there exist multiple pure-strategy Nash equilibria in which there is no free-riding. In each equilibrium the players in each group match all their efforts at the same level while best responding to the effort of the other group. Each individual player does not have any incentive to change his effort level, given the efforts of the other players. However, players within the same group have incentives to cooperate with each other and hence increase their effort levels. Lee (2009) proved that there is only one group Pareto dominant equilibrium in which no individual player or group has any incentive to deviate. In the Pareto dominant

\footnotetext{
${ }^{3}$ It is important to emphasize that when the cost of effort is convex, instead of linear, zero effort expenditures by the weak players is not an equilibrium anymore (Esteban and Ray, 2001).
} 
equilibrium, all players expend efforts, which are derived from a simple two-player contest between the weakest player in group $G$ and the weakest player in group $B$, i.e. $x_{i G}^{*}=$ $v_{N_{G} G}^{2} v_{N_{B} B} /\left(v_{N_{G} G}+v_{N_{B} B}\right)^{2}$ and $x_{i B}^{*}=v_{N_{G} G} v_{N_{B} B}^{2} /\left(v_{N_{G} G}+v_{N_{B} B}\right)^{2}$ for all $i$

\subsection{Experimental Design and Predictions}

Our experiment studies contests between symmetric groups and those between asymmetric groups. It is important to emphasize that symmetric and asymmetric refers to whether the two groups are the same or the two groups are different. All groups in all treatments, however, consist of heterogeneous players.

Table 3.1 summarizes the valuations of the players, the equilibrium efforts and the expected payoffs in contests between two symmetric groups. Both groups $G$ and $B$ have three heterogeneous players - one strong player with a high valuation of 60 and two weak players with a low valuation of 30 . The total group effort in Table 3.1 is defined as the sum of all individual efforts. The effective group effort in the perfect-substitutes contest is defined as the sum of all individual efforts, in the best-shot contest it is the maximum individual effort within a group, and in the weakest-link contest it is the minimum individual effort within a group.

Table 3.1: Contests between Symmetric Groups

\begin{tabular}{|c|c|c|c|c|c|c|c|c|c|c|}
\hline \multirow[t]{2}{*}{ Treatment } & \multirow[t]{2}{*}{ Group } & \multicolumn{2}{|c|}{$\begin{array}{l}\text { Valuation of } \\
\text { Player }\end{array}$} & \multicolumn{2}{|c|}{$\begin{array}{l}\text { Equilibrium } \\
\text { Effort of Player }\end{array}$} & \multicolumn{2}{|c|}{$\begin{array}{c}\text { Equilibrium } \\
\text { Payoff of Player }\end{array}$} & \multicolumn{2}{|c|}{$\begin{array}{l}\text { Equilibrium } \\
\text { Group Effort }\end{array}$} & \multirow{2}{*}{$\begin{array}{c}\text { Probability } \\
\text { of } \\
\text { Winning }\end{array}$} \\
\hline & & 1 & $2(3)$ & 1 & $2(3)$ & 1 & $2(3)$ & Total & Effective & \\
\hline Perfect-substitutes & $G, B$ & 60 & 30 & 15 & 0 & 15 & 15 & 15 & 15 & 0.5 \\
\hline Best-shot & $G, B$ & 60 & 30 & 15 & 0 & 15 & 15 & 15 & 15 & 0.5 \\
\hline Weakest-link & $G, B$ & 60 & 30 & 7.5 & 7.5 & 22.5 & 7.5 & 22.5 & 7.5 & 0.5 \\
\hline
\end{tabular}

In the perfect-substitutes treatment the equilibrium is unique. In the best-shot and weakest-link treatments there are multiple equilibria (the table shows group Pareto dominant equilibria) 
In the perfect-substitutes contest, the equilibrium is unique and is characterized by player $1 G$ 's and $1 B$ 's optimal effort of 15 . The weak players in the equilibrium should free-ride and expend no effort. As a result, the total group effort and the effective group effort are 15. In the best-shot contest there are multiple equilibria, which are established each time one player from group $G$ competes against one player from group $B$ as in a simple two-player contest, while other players fully free-ride. However, the group Pareto dominant equilibrium coincides with the equilibrium of the perfect-substitutes contest (Table 3.1). ${ }^{4}$ In the weakest-link contest there are multiple equilibria in which there is no free-riding. The unique group Pareto dominant equilibrium is characterized by an effort of 7.5 for all players. In the Pareto dominant equilibrium the total group effort, defined as a sum of all efforts within a group, is 22.5 ; and the effective group effort, defined as a minimum effort within a group, is 7.5.

Table 3.2: Contests between Asymmetric Groups

\begin{tabular}{|c|c|c|c|c|c|c|c|c|c|c|}
\hline \multirow[t]{2}{*}{ Treatment } & \multirow[t]{2}{*}{ Group } & \multicolumn{2}{|c|}{$\begin{array}{l}\text { Valuation of } \\
\text { Player }\end{array}$} & \multicolumn{2}{|c|}{$\begin{array}{l}\text { Equilibrium } \\
\text { Effort of Player }\end{array}$} & \multicolumn{2}{|c|}{$\begin{array}{l}\text { Equilibrium } \\
\text { Payoff of Player }\end{array}$} & \multicolumn{2}{|c|}{$\begin{array}{l}\text { Equilibrium Group } \\
\text { Effort }\end{array}$} & \multirow{2}{*}{$\begin{array}{c}\text { Probability } \\
\text { of } \\
\text { Winning }\end{array}$} \\
\hline & & 1 & $2(3)$ & 1 & $2(3)$ & 1 & $2(3)$ & Total & Effective & \\
\hline \multirow{2}{*}{ Perfect-substitutes } & $G$ & 90 & 15 & 21.6 & 0 & 32.4 & 9 & 21.6 & 21.6 & 0.60 \\
\hline & $B$ & 60 & 30 & 14.4 & 0 & 9.6 & 12 & 14.4 & 14.4 & 0.40 \\
\hline \multirow{2}{*}{ Best-shot } & $G$ & 90 & 15 & 21.6 & 0 & 32.4 & 9 & 21.6 & 21.6 & 0.60 \\
\hline & $B$ & 60 & 30 & 14.4 & 0 & 9.6 & 12 & 14.4 & 14.4 & 0.40 \\
\hline \multirow{2}{*}{ Weakest-link } & $G$ & 90 & 15 & 3.3 & 3.3 & 26.4 & 1.7 & 10.0 & 3.3 & 0.33 \\
\hline & $B$ & 60 & 30 & 6.7 & 6.7 & 33.3 & 13.3 & 20.0 & 6.7 & 0.67 \\
\hline
\end{tabular}

In the perfect-substitutes treatment the equilibrium is unique. In the best-shot and weakest-link treatments there are multiple equilibria (the table shows group Pareto dominant equilibria)

Many contests in reality take place between asymmetric groups. In the introduction we discussed a contest between the "Good Manager" group and the "Bad Manager" group, in which

\footnotetext{
${ }^{4}$ Other equilibria in the best-shot are characterized by player $2 G$ 's (or $3 G$ 's) and $2 B$ 's (or $3 B$ 's) efforts of 7.5 while others expend 0 . In these equilibria, both groups have equal probability of winning the contest. The expected payoff of player 1 is 30 , player 2(3) is 7.5, and player 3(2) is 15. One can see that these equilibria, as well as the equilibria where one strong player competes against one weak player, will cause highly asymmetric payoffs. Based on the findings of the other-regarding preferences literature (Fehr and Schmidt, 1999; Bolton and Ockenfels, 2000), we expect that the equilibrium described in Table 3.1 is most likely to be chosen by players since all players within a group earn the same expected payoffs of 15 .
} 
the asymmetry of two competing groups comes primarily from the differences between managers and workers. To capture this we examine a contest between two asymmetric groups as shown in Table 3.2. Similarly to the symmetric case, we study the effect of three contest rules: perfectsubstitutes, best-shot, and weakest-link. In each contest the composition of group $B$ is the same as in symmetric contests. In group $G$, however, the prize valuation of player $1 G$ is increased to 90 , while the prize valuation of players $2 G$ and $3 G$ is decreased to 15 . The overall valuation of both groups is held constant.

In equilibrium, group $G$ has a higher chance of winning the perfect-substitutes and bestshot asymmetric contests. This result comes from the competition between the strong players. Since player $1 G$ (“Good Manager”) has higher valuation than player $1 B$ ("Bad Manager”), player $1 G$ expends higher effort in the equilibrium (21.6 versus 14.4). As a result, group $G$ wins the contest $60 \%$ of the time. In contrast, the outcome of the weakest-link asymmetric contest depends solely on the weakest player in each group. In group $G$ the weak player's valuation is 15 , while in group $B$ the weak player's valuation is 30 . Therefore, equilibrium efforts by all players in group $G$ and group $B$ are 3.3 and 6.7. These efforts imply that in the weakest-link contest group $G$ wins $33 \%$ of the time, while group $B$ wins $67 \%$ of the time.

\subsection{The Experimental Procedures}

The experiment used subjects drawn from the population of undergraduate students at Purdue University. Computerized experimental sessions were run using z-Tree (Fischbacher, 2007) at the Vernon Smith Experimental Economics Laboratory. A total of 108 subjects participated in six experimental sessions (18 subjects per session). Upon arrival the subjects were randomly assigned to a computer. The experiment proceeded in three parts. All subjects were 
given written instructions, available in Appendix, at the beginning of each part, and an experimenter also read the instructions aloud. In the first part, similarly to Holt and Laury (2002), subjects' risk attitudes were elicited using multiple price list of 15 simple lotteries. ${ }^{5}$ At the end of the experiment, 1 out of the 15 lottery decisions made by subjects was randomly selected for payment. The second and the third parts corresponded to one symmetric and one asymmetric treatment. In three sessions we ran symmetric treatments first and in three other sessions we ran asymmetric treatments first, using the same contest rule within each session. Each subject played 30 periods in symmetric treatment and 30 periods in asymmetric treatment.

In each period subjects were randomly and anonymously placed into group $G$ or $B$ designated as either player 1,2, or 3 within that group. After each period subjects were randomly re-matched into new groups and new role assignments. Thus, in each period of the experiment all subjects had $1 / 3$ chance to play as strong and $2 / 3$ chance to play as weak player. ${ }^{6}$ At the beginning of each period, each player received an endowment of 60 experimental francs (equivalent to $\$ 1.20)^{7}$ All subjects were told that by contributing 1 franc to their individual account they would earn 1 franc, while by contributing 1 franc to their group account they could increase the chance of their group receiving the reward. Subjects could contribute any integer number of francs between 0 and 60 . After all subjects submitted their effort contributions to the group account, a computer determined the winning group. A simple lottery was used to explain how the computer chose the winning group. All players in the winning group received the reward according to their type. At the end of each period subjects were informed of group $G$ 's and $B$ 's

\footnotetext{
${ }^{5}$ Subjects were asked to state whether they preferred safe option A or risky option B. Option A yielded $\$ 1$ payoff with certainty, while option B yielded a payoff of either $\$ 3$ or $\$ 0$. The probability of receiving $\$ 3$ or $\$ 0$ varied across all 15 lotteries. The first lottery offered a 5\% chance of winning $\$ 3$ and a $95 \%$ chance of winning $\$ 0$, while the last lottery offered a $70 \%$ chance of winning $\$ 3$ and a $30 \%$ chance of winning $\$ 0$.

${ }^{6}$ This type of matching protocol was used to mitigate any concerns about fairness and inequality among subjects.

${ }^{7}$ Although we restrict the endowment to 60 , it does not affect the equilibrium. The highest equilibrium effort of the strong player (whose valuation is 90 ) is only 21.6, which is much lower than the non-binding endowment of 60.
} 
efforts, which group received the reward, and individual payoffs. Subjects were paid for 5 out of 30 periods in parts two and three at the end of the experiment. The earnings were converted into US dollars at the rate of 50 francs to $\$ 1$. On average, subjects earned $\$ 21$ each and the experimental sessions lasted for about 70 minutes.

\section{Experimental Results}

\subsection{Contests between Symmetric Groups}

Table 4.1 summarizes the average effort and payoff in symmetric contests. In the perfectsubstitutes contest the equilibrium of the game is characterized by the positive effort only for player 1. Contrary to theoretical predictions, weak players expend substantial efforts. Around $70 \%$ of all efforts expended by players 2 and 3 are positive (see Figure 4.1). We also observe that subjects in the role of player 1 expend on average an effort of 18.9, which is higher than the equilibrium effort of $15 .^{8}$ As a result of significant over-contribution, the total group effort is almost three times higher than the equilibrium and all players earn significantly lower payoffs. The significant over-contribution of efforts is consistent with Abbink et al. (2010), who find that groups in a similar perfect-substitutes contest expend four times more than the equilibrium. ${ }^{9}$

Result 1. In the perfect-substitutes contest, contrary to theoretical predictions, there is significant over-contribution of efforts by both strong and weak players.

\footnotetext{
${ }^{8}$ To support these conclusions we estimated a simple panel regression for each type of players, where the dependent variable is effort and independent variables are a constant and a period trend. The model included a random effects error structure, with the individual subject as the random effect, to account for the multiple efforts made by individual subjects. The standard errors were clustered at the session level to account for session effects. Based on a standard Wald test, conducted on estimates of a model, we found that in periods 1 through 15 both types of players expend significantly higher efforts than the predicted theoretical values ( $p$-value $<0.01)$. However, in periods 16 through 30 strong players expend efforts similar to theoretical predictions ( $p$-value $=0.38$ ).

${ }^{9}$ Significant over-contribution of efforts has been also observed in other contest studies that employ individual rather than group contestants (Millner and Pratt 1989, 1991; Davis and Reilly, 1998; Sheremeta, 2010a, 2010b).
} 
The over-contribution in perfect-substitutes contests cannot be explained by risk-aversion (Hillman and Katz, 1984; Abbink et al., 2010). In fact, given that the majority of subjects in our experiment are risk-averse $(76 \%)$ implies that on average we should observe under-contribution and not over-contribution of efforts. Also, over-contribution cannot be captured by standard social preferences literature which assumes that subjects are inequality-averse (Fehr and Schmidt, 1999; Bolton and Ockenfels, 2000). If that was the case then all subjects should have played according to the unique equilibrium defined in Table 3.1, since at this equilibrium both strong and weak players earn the same expected payoffs of 15.

\section{Table 4.1: Average Effort and Payoff in Symmetric Contests}

\begin{tabular}{|c|c|c|c|c|c|c|c|c|c|}
\hline \multirow[t]{2}{*}{ Treatment } & \multirow[t]{2}{*}{ Group } & \multicolumn{2}{|c|}{$\begin{array}{l}\text { Equilibrium } \\
\text { Effort of Player }\end{array}$} & \multicolumn{2}{|c|}{$\begin{array}{l}\text { Average Effort of } \\
\text { Player }\end{array}$} & \multicolumn{2}{|c|}{ Group Effort } & \multicolumn{2}{|c|}{$\begin{array}{c}\text { Payoff as \% of } \\
\text { Equilibrium Payoff }\end{array}$} \\
\hline & & 1 & $2(3)$ & 1 & $2(3)$ & Total & Effective & 1 & $2(3)$ \\
\hline Perfect-substitutes & $G, B$ & 15 & 0 & $18.9(0.7)$ & $10.8(0.4)$ & 40.5 & 40.5 & $74.0 \%$ & $28.0 \%$ \\
\hline Best-shot & $G, B$ & 15 & 0 & $15.2(0.8)$ & $4.7(0.4)$ & 24.6 & 19.9 & $98.4 \%$ & $68.9 \%$ \\
\hline Weakest-link & $G, B$ & 7.5 & 7.5 & $7.7(0.4)$ & $7.0(0.2)$ & 21.6 & 4.8 & $99.3 \%$ & $107.0 \%$ \\
\hline
\end{tabular}

Standard error of the mean in parentheses

\section{Figure 4.1: Distribution of Effort (Perfect-Substitutes)}
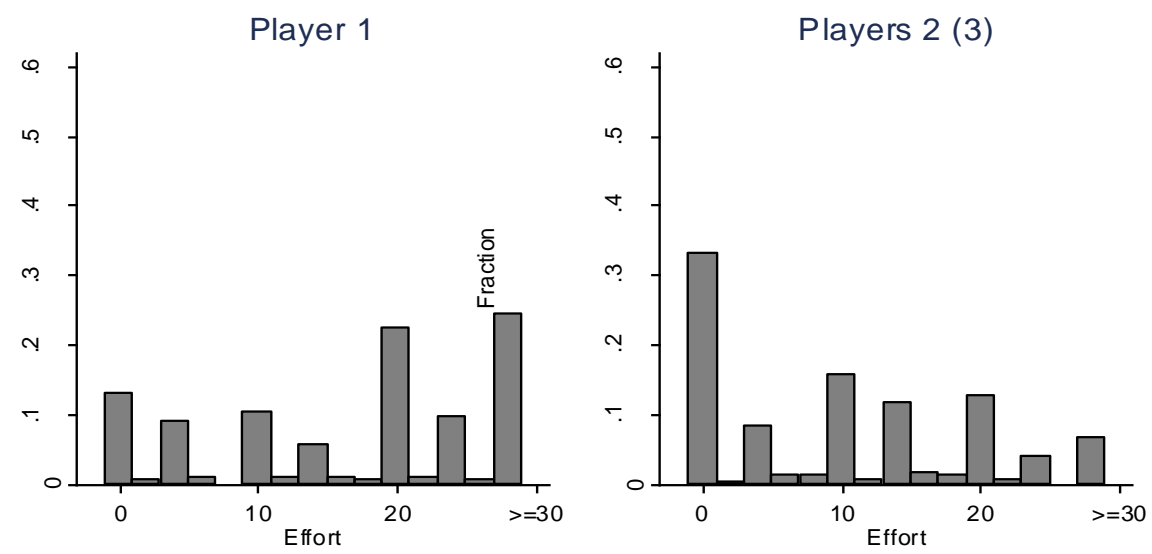

Although risk-aversion and inequality-aversion cannot explain significant overcontribution of efforts, there are several other possible explanations. First, subjects may have a 
non-monetary utility of winning which is not accounted by a general theory (Sheremeta, 2010b). Second, it is possible that subjects expend significantly higher efforts because each period they receive a "free" endowment of 60 francs. Note that this endowment is substantially higher than the Nash equilibrium predictions. While the endowment itself has no theoretical impact, it certainly may have a behavioral impact, causing subjects to over-contribute. Finally, the most likely explanation for over-contribution comes from a rapidly developing literature in economics on social group identity (Akerlof and Kranton, 2000; Chen and Li, 2009; Sutter, 2009). By expending positive efforts in the perfect-substitutes contest players always contribute to the group performance. Therefore, subjects may identify themselves as a group and be influenced by this group identification (Kugler et al., 2010). Obviously, the group identification shifts players' attention from self-interested profit-maximizing behavior to altruistic group-maximizing behavior and thus may cause over-contribution of efforts. ${ }^{10}$

The striking difference between the best-shot and perfect-substitutes contests is that in the symmetric best-shot contest most subjects learn to play an equilibrium in which weak players free-ride on the effort expenditures of strong players. Figure 4.2 displays the effort made by player 1 and the corresponding maximum individual effort in the group. The size of the bubble indicates the frequency of observation (the total number of observations is 360). For example, the biggest bubble on the graph indicates that 49 times player 1's effort of 20 turned out to be the highest effort within a group. About $75 \%$ of all observations lie on the 45 degree line, indicating that player 1 most frequently has the highest effort within a group. Moreover, in the best-shot

\footnotetext{
${ }^{10}$ Players 1,2 , and 3 receive the total prize of $120=60+30+30$. Thus, if all players in group $G$ (group $B$ ) maximize their total group payoff, instead of maximizing individual payoffs, then the equilibrium group effort should be 30 , instead of 15 (Table 4.1). This equilibrium effort is derived from a simple contest between two players for a prize of value 120 (Tullock, 1980). If the above argument is correct and social group identity promotes individual members to act as one, then the average group effort observed in the experiment is only $30 \%$ higher than the equilibrium group effort (40.5 versus 30$)$.
} 
contest only $28 \%$ of efforts made by players 2 and 3 are above 0 (compared to $70 \%$ in the perfect-substitutes contest).

Result 2. In the best-shot contest most of the efforts are made by strong players, while weak players tend to free-ride.

Figure 4.2: Frequency of Player 1 Having the Highest Effort in the Group (Best-Shot)

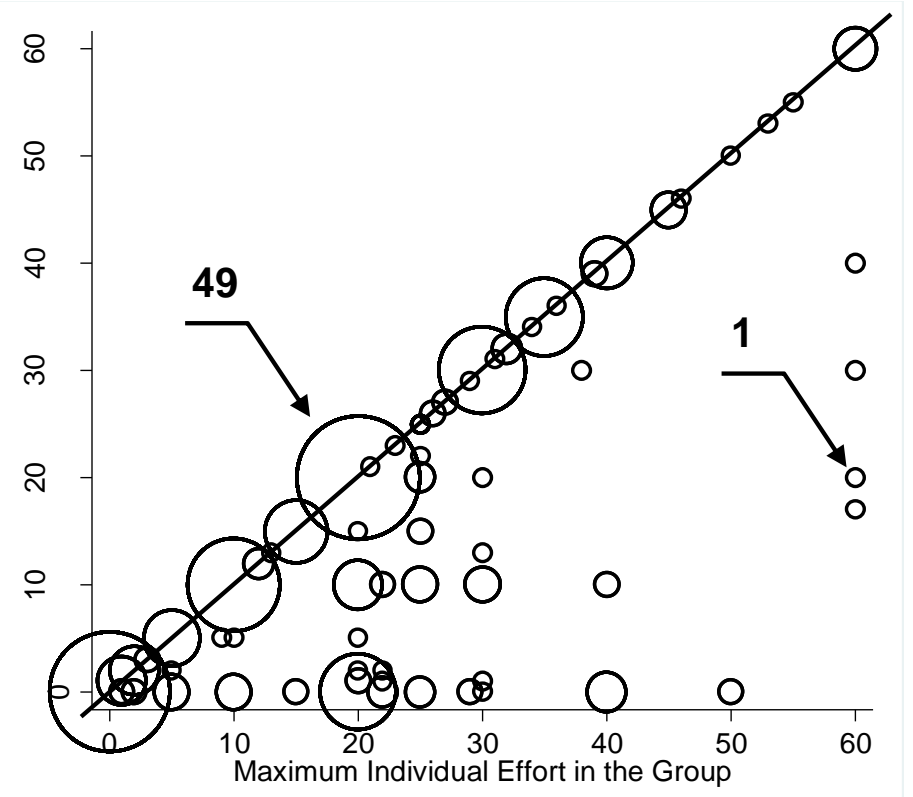

Overall, the behavior we observe in the best-shot contest is consistent with theoretical predictions. ${ }^{11}$ This finding is different from previous findings of Harrison and Hirshleifer (1989) who document that, in the best-shot public goods game, players expend four times higher efforts than predicted. The difference between our findings and findings of Harrison and Hirshleifer is likely due to the fact that, instead of homogenous players, we have heterogeneous players. In the equilibrium of the best-shot contest only one player should expend positive effort while other players should expend no effort. The introduction of heterogeneity between players results in a

\footnotetext{
${ }^{11}$ As mentioned in Section 3.2 (see footnote 4), in a case when some weak players expend sufficiently high efforts, it can be optimal for strong players to expend no effort. This may explain why $26 \%$ of efforts made by strong players are 0 in the best-shot contest, compared to only $12 \%$ in the perfect-substitutes contest.
} 
focal point where only the strong player expends positive effort (Schelling, 1960; Ochs, 1995; Crawford et al., 2008). This finding suggests that the heterogeneity between players serves as a coordination device and thus it can be used to solve the coordination failure problem in volunteer's dilemma games (Diekmann, 1985, 1993).

Next we look at the behavior of players in the symmetric weakest-link contest. The striking difference between the weakest-link contest and the two other contests is that, in the weakest-link contest, all players expend very similar efforts. Table 4.1 reports that player 1 on average expends effort of 7.7 and players 2 and 3 expend efforts of 7 . In the Pareto dominant equilibrium all players should expend 7.5 as their effort. ${ }^{12}$

Result 3. In the weakest-link contest both strong and weak players expend similar positive efforts, at levels consistent with the group Pareto dominant equilibrium.

It is important to emphasize, however, that nearly $50 \%$ of all individual efforts do not precisely coincide with the minimum individual effort within the group (the effective group effort in Table 4.1) suggesting some coordination failure. Figure 4.3 displays the distribution of efforts in the weakest-link contest. Most frequently, strong and weak players coordinate their efforts around 5. Consequently, the average effective group effort of 4.8 is lower than the optimal Pareto dominant effort of 7.5. Figure 4.4 displays the dynamics of the average effort and the standard deviation in the weakest-link contest. As players become more experienced, the within-group standard deviation decreases. This is a good indication of convergence towards the equilibrium prediction of symmetric efforts. At equilibrium, of course, the standard deviation should be zero.

\footnotetext{
${ }^{12}$ Based on a standard Wald test, conducted on estimates of a random effects model, we cannot reject the hypothesis that the weak players expend the Pareto equilibrium effort in the first 15 periods $(p$-value $=0.57$ ) and in the last 15 periods $(p$-value $=0.88)$ of the experiment. Similarly, the expenditures of strong players are not significantly different from the equilibrium in the first 15 periods $(p$-value $<0.86)$ and in the last 15 periods $(p$-value $=0.59)$ of the experiment.
} 


\section{Figure 4.3: Distribution of Effort (Weakest-Link)}

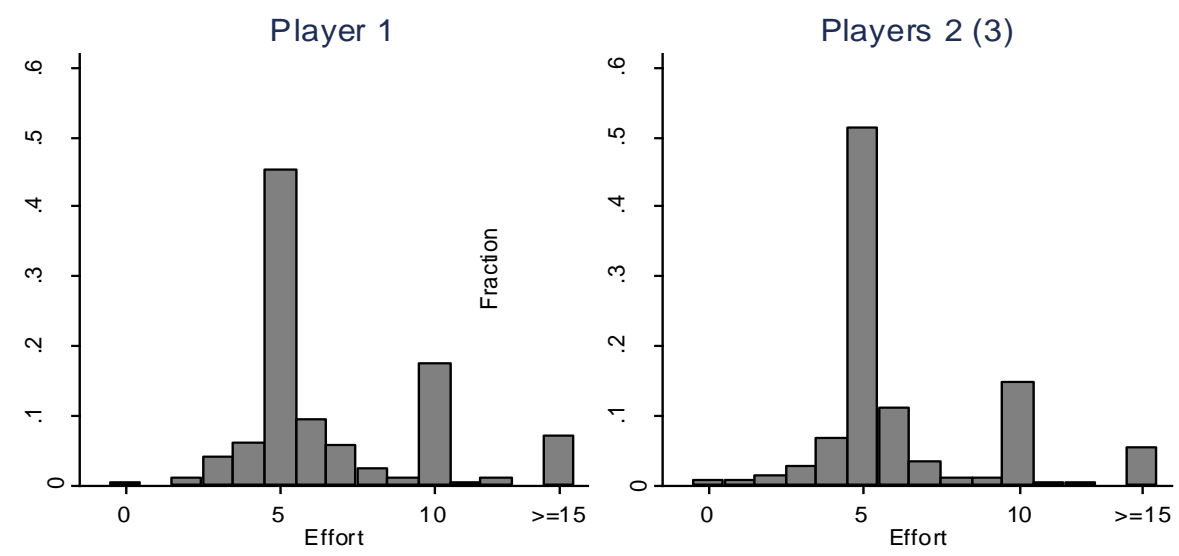

Figure 4.4: Average Effort (Weakest-Link)

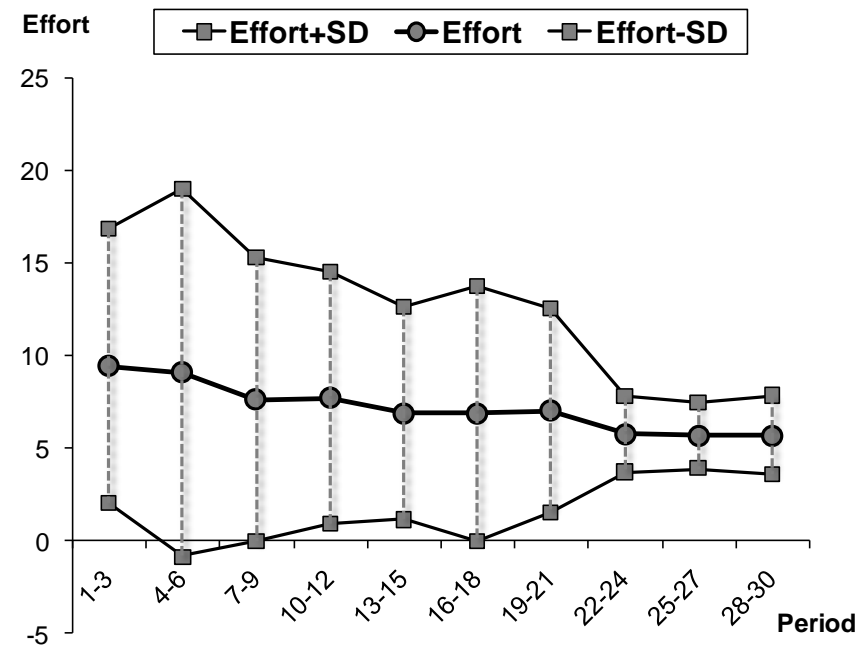

Overall, the behavior observed in the weakest-link contest is consistent with the Pareto dominant equilibrium. This finding contrasts with the literature on coordination games with Pareto-ranked equilibria (Van Huyck et al., 1990, 1991; Cooper et al., 1990, 1992). The seminal studies by Van Huyck et al. (1990) and Cooper et al. (1990) document that coordination failure is a common phenomenon in the laboratory. A number of studies have tried to resolve the coordination failure through pre-play communication (Cooper et al., 1992), repetition and fixedmatching protocols (Clark and Sefton, 2001), and gradual increase in the group size (Weber, 
2006). Our experiment points out that introduction of between-group competition may be another solution to the coordination failure problem. ${ }^{13}$

\subsection{Contests between Asymmetric Groups}

The asymmetric contests had two asymmetric groups competing against each other under three different contest rules. Table 4.2 summarizes the average individual and group efforts in all asymmetric contests. As in the symmetric case, weak players 2 and 3 expend positive efforts in the asymmetric perfect-substitutes contest, although the equilibrium predicts positive effort only for strong player 1 . This is consistent with the previous Result 1. In line with Result 2, most of the efforts in the asymmetric best-shot contest are made by strong players while weak players free-ride. Finally, in line with Result 3, strong and weak players in the asymmetric weakest-link contest learn to coordinate their efforts at the same level.

Table 4.2: Average Effort and Probability of Winning in Asymmetric Contests

\begin{tabular}{|c|c|c|c|c|c|c|c|c|c|}
\hline \multirow[t]{2}{*}{ Treatment } & \multirow[t]{2}{*}{ Group } & \multicolumn{2}{|c|}{$\begin{array}{l}\text { Equilibrium } \\
\text { Effort of Player }\end{array}$} & \multicolumn{2}{|c|}{$\begin{array}{c}\text { Average } \\
\text { Effort of Player }\end{array}$} & \multicolumn{2}{|c|}{ Group Effort } & \multicolumn{2}{|c|}{$\begin{array}{l}\text { Probability of } \\
\text { Winning }\end{array}$} \\
\hline & & 1 & $2(3)$ & 1 & $2(3)$ & Total & Effective & Equilibrium & Actual \\
\hline \multirow{2}{*}{ Perfect-substitutes } & $G$ & 21.6 & 0 & $25.0(1.3)$ & $7.2(0.6)$ & 39.5 & 39.5 & 0.60 & 0.41 \\
\hline & $B$ & 14.4 & 0 & $19.1(1.1)$ & $12.0(0.6)$ & 43.1 & 43.1 & 0.40 & 0.59 \\
\hline \multirow{2}{*}{ Best-shot } & $G$ & 21.6 & 0 & $32.9(1.2)$ & $4.1(0.6)$ & 41.0 & 34.3 & 0.60 & 0.56 \\
\hline & $B$ & 14.4 & 0 & $19.4(1.5)$ & $5.9(0.6)$ & 31.2 & 24.5 & 0.40 & 0.44 \\
\hline \multirow{2}{*}{ Weakest-link } & $G$ & 3.3 & 3.3 & $7.5(0.4)$ & $5.6(0.2)$ & 18.8 & 4.0 & 0.33 & 0.42 \\
\hline & $B$ & 6.7 & 6.7 & $7.2(0.4)$ & $6.8(0.2)$ & 20.8 & 4.9 & 0.67 & 0.58 \\
\hline
\end{tabular}

Standard error of the mean in parentheses

The unique feature of contests between asymmetric groups is that, depending on the contest rule, either group $G$ or group $B$ has a higher probability of winning in the equilibrium.

\footnotetext{
13 Similar result is established by Bornstein et al. (2002), who find that competition between groups improves collective efficiency relative to the base line treatment of Van Huyck et al. (1990). The main difference of our study is that all players in the losing group had to forfeit their efforts, whereas in Bornstein et al. they simply received zero payoffs.
} 
For example, theory predicts that in the perfect-substitutes contest, group $G$ has a higher chance of winning. The data clearly rejects this prediction. We estimated a probit model where the dependent variable is winning and the independent variables are individual subject dummies, session dummies, and a dummy for group $G$. The group $G$ dummy-variable is negative and significant $(p$-value $<0.01)$.

Result 4. Contrary to theoretical predictions, group $G$ wins significantly less in the perfect-substitutes contest than group $B$.

Theory predicts that player $1 B$, whose valuation is 60 , should be discouraged by player $1 G$, whose valuation is 90 . Given that the effective competition in equilibrium is only between strong players, group $G$ should have a higher probability of winning the contest. Nevertheless, Table 4.2 shows that, in the perfect-substitutes contest, player $1 B$ is not discouraged by player $1 G .{ }^{14}$ Moreover, player $1 B$ receives significantly more support from weak players $2 B$ and $3 B$ than player $1 G$ receives from players $2 G$ and $3 G$. As a result, instead of winning the contest $40 \%$ of the time, group $B$ wins the contest $59 \%$ of the time.

In the best-shot and weakest-link contests the story is quite different. Consistent with theoretical predictions, group $G$ wins more often in the best-shot contest than group $B$. The estimation of a random effects probit model, where the dependent variable is winning and the independent variable is a dummy for group $G$, indicates significant difference ( $p$-value $<0.01$ ). Theory also predicts that group $G$ has a lower probability of winning the weakest-link contest. This prediction is supported by the data $(p$-value $<0.01)$.

Result 5. Consistent with theoretical predictions, group $G$ wins more often than group $B$ in the best-shot contest and less often in the weakest-link contest.

\footnotetext{
${ }^{14}$ Note that although the equilibrium effort of player $1 B$ in the asymmetric perfect-substitutes contest (Table 4.2) is lower than in the symmetric perfect-substitutes contest (14.4 versus 15), the actual average effort is slightly higher (19.1 versus 18.9), indicating no discouragement effect.
} 
Why does group $G$ win the best-shot contest but lose the weakest-link contest? The outcome of the best-shot contest depends only on strong players. As previously established (Result 2), neither $1 G$ nor $1 B$ players receive any significant support from weak players in bestshot contests. Consequently, competition occurs between strong players only, with player $1 G$ having a higher valuation and thus a substantial advantage over player $1 B$. On the other hand, the outcome of the weakest-link contest depends only on the weakest player in each group. Since the weakest player in group $G$ has a lower valuation than in group $B$ (15 versus 30), group $G$ has a lower probability of winning the contest. ${ }^{15}$ To summarize, asymmetric valuations help group $G$ in the best-shot contest but not in the weakest-link contest.

The findings described in this section answer one of the questions that we posed in the introduction, namely, which group will win the contest: the "Good Manager" group with the better motivated manager or the "Bad Manager" group with the better motivated workers? It turns out that the outcome of the competition depends upon the underlying rules. The group with the better motivated manager is more likely to win the best-shot contest (Result 5), while the group with the better motivated workers is more likely to win the weakest-link and perfectsubstitutes contests (Results 4 and 5).

One interpretation of our results relates to managerial compensation schemes. Let's say a CEO has a bonus pool which can be used to motivate a team of one manager and several workers. By wisely accounting for the type of underlying contest, the CEO can increase the team's chance of success. For example, if the team is participating in the best-shot type of contest then the CEO should allocate the largest bonus to the manager. However, given the fact

\footnotetext{
${ }^{15}$ Table 4.2 shows that in the weakest-link contest the strong player in group G expends significantly higher effort than weak players. One interpretation of this observation is that the strong player tries to coordinate with weak players at a substantially higher level than the equilibrium, because the prize valuation of the strong player is six times higher than the prize valuation of weak players.
} 
that the majority of real life contests require considerable group coordination (as in the weakestlink) and high level of joint effort (as in the perfect-substitutes), it might not be optimal to allocate a large bonus to the manager.

\section{Discussion and Conclusions}

This experiment shows that individual behavior in contests between symmetric groups and those between asymmetric groups depends upon a player's type and the rules that regulate the competition. In contests, where individual efforts are perfect substitutes, both strong and weak players significantly over-contribute their efforts. In best-shot contests, where the performance of a group depends on the best performer within the group, most of the effort is expended by strong players while weak players free-ride. In weakest-link contests, where the group performance depends on the worst performer within the group, there is almost no freeriding and all players expend similar positive efforts.

What are the implications of our findings? First, our findings point out that introduction of between-group competition and heterogeneity between players (as in the weakest-link and best-shot contests) can solve the coordination failure problem in games with Pareto-ranked equilibria (such as the minimum effort and best-shot public goods games). Second, our findings have implications for designing contests between groups in a workplace. By organizing work groups in specific ways, with specific rules, one can effectively control the competitive environment within a workplace. For example, if the administrator wants to encourage the highest performance from the strongest players, he should employ a best-shot contest. In such a contest, as our results point out, most of the efforts within a group will be made by strong players. If the objective is to reduce free-riding, the contest designer should choose to use the 
weakest-link contest. It is important to emphasize, however, that choosing one contest over another comes at a cost. By choosing the best-shot contest, the designer should anticipate strong free-riding behavior from weak players. By choosing the weakest-link contest, the designer should anticipate little group effort as well as poor performance by strong players. Therefore, the general conclusion from our findings is that the advantage of one contest rule over another comes at a cost.

This study opens a new avenue for future research. First natural question is: how robust our experimental results when there are more than two groups in a contest or more than three players within each group? One conjecture is that increasing the group size and/or the number of groups will lead to more free-riding (Isaac and Walker, 1988). Second, it would be interesting to see how robust our findings are under alternative contest success functions and convex costs (Baik et al., 2001; Esteban and Ray, 2001). Another extension is to allow sequential contribution of efforts by weak players and then by strong players within each group. Such modification should not change the Nash equilibrium of the contest. ${ }^{16}$ However, behaviorally, sequential and simultaneous contests are very different. It is likely that the sequential design will lead subjects to behave more in the line with theoretical predictions (Harrison and Hirshleifer, 1989). Future research should also consider other realistic extensions to the group-contest setting, including budget constraints, incomplete information, communication, and endogenous group formation.

\footnotetext{
${ }^{16}$ It will, however, provide a unique subgame perfect equilibrium in the best-shot and weakest-link contests.
} 


\section{References}

Abbink. K., Brandts, J., Herrmann, B., \& Orzen, H. (2010). Inter-Group Conflict and IntraGroup Punishment in an Experimental Contest Game. American Economic Review, 100, 420-447.

Ahn, T.K., R, Isaac, M., \& Salmon, T.C. (2010). Rent Seeking in Groups. International Journal of Industrial Organization, forthcoming.

Akerlof, G.A., \& Kranton, R.E. (2000). Economics and Identity. Quarterly Journal of Economics, 115, 715-753.

Baik, K.H. (1993). Effort Levels in Contests: The Public-Good Prize Case. Economics Letters, 41, 363-67.

Baik, K.H. (2008). Contests with group-specific public-good prizes. Social Choice and Welfare, 30, 103-117.

Baik, K.H., Kim, In-Gyu, \& Na, S. (2001). Bidding for a group-specific public-good prize. Journal of Public Economics, 82, 415-429.

Bliss, C., \& Nalebuff, B. (1984). Dragon-slaying and ballroom dancing: The private supply of a public good. Journal of Public Economics, 25, 1-12.

Bolton, G.E., \& Ockenfels, A. (2000). ERC - A Theory of Equity, Reciprocity, and Competition. American Economic Review, 90, 166-193.

Bornstein, G., Gneezy, U., \& Nagel, R. (2002). The effect of intergroup competition on group coordination: An experimental study. Games and Economic Behavior, 41, 1-25.

Chen, Y., \& Li, S.X. (2009). Group Identity and Social Preferences, American Economic Review, 99, 431-57.

Chowdhury, S., Lee, D., \& Sheremeta, R.M. (2010). Group Contests with CES Impact Functions, Purdue University, Working Paper.

Clark, K., \& Sefton, M. (2001). Repetition and signalling: Experimental evidence from games with efficient equilibria. Economics Letters, 70, 357-362.

Cooper, R., De Jong, D., Forsythe, R., \& Ross, T. (1990). Selection criteria in coordination games: Some experimental results. American Economic Review, 80, 218-233.

Cooper, R., De Jong, D., Forsythe, R., \& Ross, T. (1992). Communication in coordination games. Quarterly Journal of Economics, 107, 739-771.

Cornes, R. (1993). Dyke Maintenance and Other Stories: Some Neglected Types of Public Goods. Quarterly Journal of Economics. 108, 259-71.

Crawford, V.P., Gneezy, U., \& Rottenstreich, Y. (2008). The Power of Focal Points Is Limited: Even Minute Payoff Asymmetry May Yield Large Coordination Failures, American Economic Review, 98, 1443-58.

Davis, D., \& Reilly, R. (1998). Do many cooks always spoil the stew? An experimental analysis of rent seeking and the role of a strategic buyer. Public Choice, 95, 89-115.

Diekmann, A. (1985). Volunteer's Dilemma. Journal of Conflict Resolution, 29, 605-610.

Diekmann, A. (1993). Cooperation in an Asymmetric Volunteer's Dilemma Game. Theory and Experimental Evidence. International Journal of Game Theory, 22, 75-85.

Ericsson, K.A., \& Charness, N. (1994). Expert performance: Its structure and acquisition. American Psychologist, 49, 725 - 747.

Esteban, J., \& Ray, D. (2001). Collective Action and Group Size Paradox. American Political Science Review, 95, 663-672.

Fehr, E., \& Schmidt, K.M. (1999). A Theory of Fairness, Competition, and Cooperation. Quarterly Journal of Economics, 114, 817-868. 
Fischbacher, U. (2007). z-Tree: Zurich Toolbox for Ready-made Economic experiments. Experimental Economics, 10, 171-178.

Gunnthorsdottir, A., \& Rapoport, A. (2006). Egalitarian vs. proportional profit-sharing rules in multi-level collective action problems. Organizational Behavior and Human Decision Processes, 101, 184-199.

Harrison, G. W., \& Hirshleifer, J. (1989). An Experimental Evaluation of Weakest Link/Best Shot Models of Public Goods. Journal of Political Economy, 97, 201-225.

Hillman, A.L., \& Katz, E. (1984). Risk-averse rent seekers and the social cost of monopoly power. Economic Journal, 94, 104-110.

Hirshleifer, J. (1983). From Weakest Link to Best-Shot: The Voluntary Provision of Public Goods. Public Choice, 41, 371-386

Holt, C.A., \& Laury, S.K. (2002). Risk Aversion and Incentive Effects. American Economic Review, 92, 1644-1655.

Isaac, R.M., \& Walker, J. (1988). Group Size Hypotheses of Public Goods Provision: The Voluntary Contribution Mechanism. Quarterly Journal of Economics, 103, 179-200.

Katz, E., Nitzan, S., \& Rosenberg, J. (1990). Rent-seeking for pure public goods. Public Choice, $65,49-60$.

Konrad, K.A. (2009). Strategy and Dynamics in Contests. Oxford University Press.

Kugler, T., Rapoport A., \& Pazy, A. (2010). Public good provision in inter-group conflicts: Effects of asymmetry and profit-sharing rule. Journal of Behavioral Decision Making, forthcoming.

Lee, D. (2009). Weakest-link contest with group-specific public good prizes, Virginia Tech, Working Paper.

Millner E. L., \& Pratt, M. D. (1991). Risk aversion and rent seeking: An extension and some experimental evidence. Public Choice, 69, 91-92.

Millner, E.L., \& Pratt, M.D. (1989). An experimental investigation of efficient rent-seeking. Public Choice, 62, 139-151.

Nalbantian, H. R., \& Schotter, A. (1997). Productivity under group incentives: An experimental study. American Economic Review, 87, 314-341.

Nti, K. (1998). Effort and performance in group contests. European Journal of Political Economy, 14, 769-781.

Ochs, J. (1995). Coordination problems. In J. H. Kagel \& A. E. Roth (Eds.), Handbook of experimental economics. Princeton: Princeton University Press, pp. 195-251.

Olson, M. (1965). The Logic of Collective Action: Public Goods and the Theory of Groups, Harvard University Press, Cambridge, MA.

Palfrey, T. R. and Rosenthal, H. (1983). A Strategic Calculus of Voting. Public Choice, 41, 7-53.

Potters, J.C., De Vries, C.G., \& Van Linden, F. (1998). An experimental examination of rational rent seeking. European Journal of Political Economy, 14, 783-800.

Rapoport, A., \& Bornstein, G. (1987). Intergroup competition for the provision of binary public goods. Psychological Review, 94, 291-299.

Riaz, K., Shogren, J.F., \& Johnson, S.R. (1995). A general model of rent seeking for public goods. Public Choice, 82, 243-259.

Schelling, T. C. (1960). The Strategy of Conflict. Cambridge, Massachusetts: Harvard University Press.

Schram, A., \& Sonnemans, J. (1996). Why people vote: Experimental evidence. Journal of Economic Psychology, 17, 417-442. 
Sheremeta, R.M. (2010a). Contest Design: An Experimental Investigation. Economic Inquiry, forthcoming.

Sheremeta, R.M. (2010b). Experimental Comparison of Multi-Stage and One-Stage Contests. Games and Economic Behavior, 68, 731-747.

Sutter, M. (2009). Individual behavior and group membership: Comment. American Economic Review, 99, 2247-2257.

Sutter, M., \& Strassmair, C. (2009). Communication, cooperation and collusion in team tournaments - An experimental study. Games and Economic Behavior, 66, 506-525.

Tullock, G. (1980). Efficient Rent Seeking. In J.M. Buchanan, R.D. Tollison, G. Tullock, (Eds.), Toward a theory of the rent-seeking society. College Station, TX: Texas A\&M University Press, pp. 97-112.

Van Huyck, J. B., Battalio, R. C., \& Beil, R. O. (1990). Tacit coordination games, strategic uncertainty, and coordination failure. American Economic Review, 80, 234-248.

Van Huyck, J. B., Battalio, R. C., \& Beil, R. O. (1991). Strategic uncertainty, equilibrium selection, and coordination failure in average opinion games. Quarterly Journal of Economics, 106, 885-911.

Weber, R. (2006). Managing growth to achieve efficient coordination in large groups. American Economic Review, 96, 114-126. 


\section{Appendix - The Instructions for the Perfect-Substitutes Treatment}

\section{GENERAL INSTRUCTIONS}

This is an experiment in the economics of strategic decision making. Various research agencies have provided funds for this research. The instructions are simple. If you follow them closely and make appropriate decisions, you can earn an appreciable amount of money.

The experiment will proceed in three parts. Each part contains decision problems that require you to make a series of economic choices which determine your total earnings. The currency used in Part 1 of the experiment is U.S. Dollars. The currency used in Parts 2 and 3 of the experiment is francs. Francs will be converted to U.S. Dollars at a rate of $\mathbf{5 0}$ francs to 1 dollar. At the end of today's experiment, you will be paid in private and in cash. 18 participants are in today's experiment.

It is very important that you remain silent and do not look at other people's work. If you have any questions, or need assistance of any kind, please raise your hand and an experimenter will come to you. If you talk, laugh, exclaim out loud, etc., you will be asked to leave and you will not be paid. We expect and appreciate your cooperation.

At this time we proceed to Part 1 of the experiment.

\section{INSTRUCTIONS FOR PART 1 \\ YOUR DECISION}

In this part of the experiment you will be asked to make a series of choices in decision problems. How much you receive will depend partly on chance and partly on the choices you make. The decision problems are not designed to test you. What we want to know is what choices you would make in them. The only right answer is what you really would choose.

For each line in the table in the next page, please state whether you prefer option A or option B. Notice that there are a total of $\mathbf{1 5}$ lines in the table but just one line will be randomly selected for payment. You ignore which line will be paid when you make your choices. Hence you should pay attention to the choice you make in every line. After you have completed all your choices a token will be randomly drawn out of a bingo cage containing tokens numbered from 1 to 15 . The token number determines which line is going to be paid.

Your earnings for the selected line depend on which option you chose: If you chose option A in that line, you will receive $\mathbf{\$ 1}$. If you chose option B in that line, you will receive either $\mathbf{\$ 3}$ or $\mathbf{\$ 0}$. To determine your earnings in the case you chose option B there will be second random draw. A token will be randomly drawn out of the bingo cage now containing twenty tokens numbered from 1 to 20. The token number is then compared with the numbers in the line selected (see the table). If the token number shows up in the left column you earn $\$ 3$. If the token number shows up in the right column you earn $\$ 0$.

\section{Any questions?}




\section{Participant ID}

\begin{tabular}{|c|c|c|c|c|}
\hline $\begin{array}{l}\text { Decision } \\
\text { No. }\end{array}$ & $\begin{array}{l}\text { Option } \\
\text { A }\end{array}$ & & $\begin{array}{l}\text { ption } \\
\text { B }\end{array}$ & $\begin{array}{l}\text { Please } \\
\text { choose } \\
\text { A or B }\end{array}$ \\
\hline 1 & $\$ 1$ & $\$ 3$ never & $\begin{array}{l}\text { \$0 if } 1,2,3,4,5,6,7,8,9,10,11,12,13 \text {, } \\
14,15,16,17,18,19,20\end{array}$ & \\
\hline 2 & $\$ 1$ & $\mathbf{\$ 3}$ if 1 comes out of the bingo cage & $\begin{array}{l}\text { \$0 if } 2,3,4,5,6,7,8,9,10,11,12,13,14,15 \text {, } \\
16,17,18,19,20\end{array}$ & \\
\hline 3 & $\$ 1$ & $\$ 3$ if 1 or 2 comes out & $\begin{array}{l}\text { \$0 if } 3,4,5,6,7,8,9,10,11,12,13,14,15, \\
16,17,18,19,20\end{array}$ & \\
\hline 4 & $\$ 1$ & $\mathbf{\$ 3}$ if 1,2 , or 3 & $\begin{array}{l}\text { \$0 if } 4,5,6,7,8,9,10,11,12,13,14,15 \text {, } \\
16,17,18,19,20\end{array}$ & \\
\hline 5 & $\$ 1$ & $\mathbf{\$ 3}$ if $1,2,3,4$ & $\begin{array}{l}\text { \$0 if } 5,6,7,8,9,10,11,12,13,14,15 \text {, } \\
16,17,18,19,20\end{array}$ & \\
\hline 6 & $\$ 1$ & $\mathbf{\$ 3}$ if $1,2,3,4,5$ & $\begin{array}{l}\text { \$0 if } 6,7,8,9,10,11,12,13,14,15 \text {, } \\
16,17,18,19,20\end{array}$ & \\
\hline 7 & $\$ 1$ & $\mathbf{\$ 3}$ if $1,2,3,4,5,6$ & $\begin{array}{l}\text { \$0 if } 7,8,9,10,11,12,13,14,15 \text {, } \\
16,17,18,19,20\end{array}$ & \\
\hline 8 & $\$ 1$ & $\mathbf{\$ 3}$ if $1,2,3,4,5,6,7$ & $\begin{array}{l}\text { \$0 if } 8,9,10,11,12,13,14,15 \\
16,17,18,19,20\end{array}$ & \\
\hline 9 & $\$ 1$ & $\mathbf{\$ 3}$ if $1,2,3,4,5,6,7,8$ & $\begin{array}{l}\mathbf{\$ 0} \text { if } 9,10,11,12,13,14,15 \\
16,17,18,19,20\end{array}$ & \\
\hline 10 & $\$ 1$ & $\mathbf{\$ 3}$ if $1,2,3,4,5,6,7,8,9$ & $\mathbf{\$ 0}$ if $10,11,12,13,14,15,16,17,18,19,20$ & \\
\hline 11 & $\$ 1$ & $\mathbf{\$ 3}$ if $1,2,3,4,5,6,7,8,9,10$ & $\$ \mathbf{0}$ if $11,12,13,14,15,16,17,18,19,20$ & \\
\hline 12 & $\$ 1$ & $\mathbf{\$ 3}$ if $1,2,3,4,5,6,7,8,9,10,11$ & $\$ \mathbf{0}$ if $12,13,14,15,16,17,18,19,20$ & \\
\hline 13 & $\$ 1$ & $\mathbf{\$ 3}$ if $1,2,3,4,5,6,7,8,9,10,11,12$ & $\$ \mathbf{0}$ if $13,14,15,16,17,18,19,20$ & \\
\hline 14 & $\$ 1$ & $\mathbf{\$ 3}$ if $1,2,3,4,5,6,7,8,9,10,11,12,13$ & $\mathbf{\$ 0}$ if $14,15,16,17,18,19,20$ & \\
\hline 15 & $\$ 1$ & $\begin{array}{l}\mathbf{\$ 3} \text { if } 1,2,3,4,5,6,7,8,9,10 \\
11,12,13,14\end{array}$ & $\$ 0$ if $15,16,17,18,19,20$ & \\
\hline
\end{tabular}




\section{INSTRUCTIONS FOR PART 2 \\ YOUR DECISION}

The second part of the experiment consists of $\mathbf{3 0}$ decision-making periods. At the beginning of each period, you will be randomly and anonymously placed into a group of $\mathbf{3}$ people (group A or B). Either group A or group B will receive the reward of $\mathbf{1 2 0}$ francs at the end of each period. In addition to your group assignment you will also be randomly assigned a specific type in the group (type 1,2, or 3). Your type will determine how the reward is shared within the group. Each period your group as well as your type will be changed.

Each period you will be given an initial endowment of $\mathbf{6 0}$ francs and asked to decide how much to allocate to the group account or the individual account. You may allocate any integer number of francs between $\mathbf{0}$ and $\mathbf{6 0}$. An example of your decision screen is shown below.

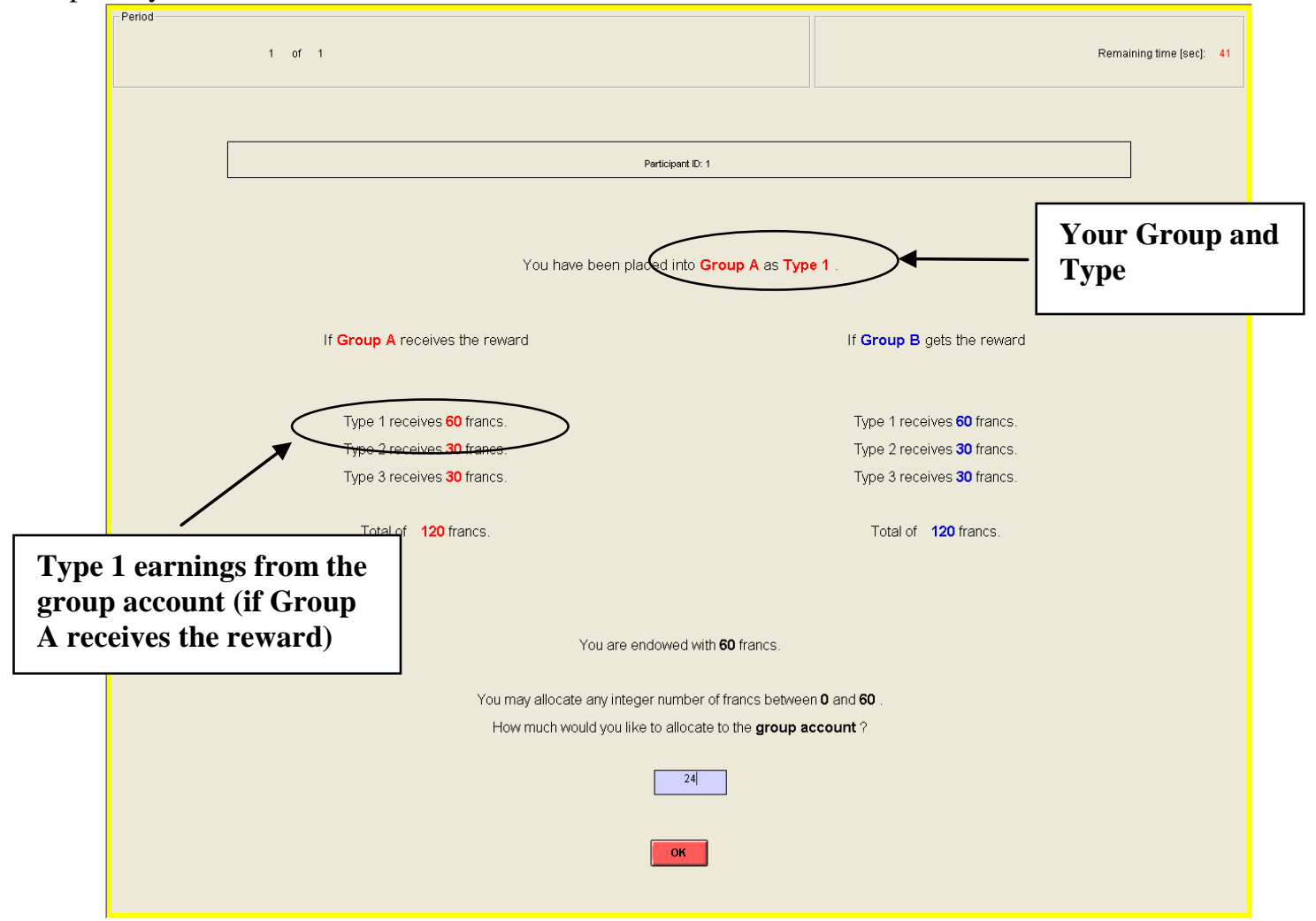

At the beginning of each period you will see which group and what type you are assigned to (as shown at the top of the screen). You will also see the composition of both group A and group B, thus you will know the types of participants in both groups (as shown on the right and left columns of the screen).

\section{YOUR EARNINGS}

After all participants have made their decisions, your earnings for the period are calculated. These earnings will be converted to cash and paid at the end of the experiment if the current period is one of the five periods that is randomly chosen for payment.

1) Your period earnings are the sum of the earnings from your individual account and the earnings from your group account.

2) For each franc in your individual account, you will earn 1 franc in return. So, if you keep all 60 francs that you are endowed with to your individual account you will earn 60 francs. But you can also earn some francs from your group account.

3) By contributing to the group account you are increasing the chance of receiving the reward for your group. If the total number of francs in your group account exceeds the total number of francs in the other group account, your group has higher chance of receiving the reward. If your group receives the reward then in addition to the earnings from your individual account you receive the reward from your group account which is determined by your type. A group can never guarantee itself the reward. However, by increasing your contribution, you can increase your group's chance of receiving the reward.

4) The computer will assign the reward either to your group or to the other group, via a random draw. So, in each period, only one of the two groups can obtain the reward. 


\section{Example 1. Random Draw}

This is a hypothetical example used to illustrate how the computer is making a random draw. Think of the random draw in the following way. For each franc in group A's account the computer puts 1 red token into a bingo cage and for each franc in group B's account the computer puts $\mathbf{1}$ blue token. Then the computer randomly draws one token out of the bingo cage. If the drawn token is red group A receives the reward, if the token is blue group B receives the reward. Assume that members of both group A and B have allocated their francs in the following way (as shown on the Table 1 below).

Table 1 - Allocation of francs by all types in group A and B

\begin{tabular}{|c|c|c|c|}
\hline $\begin{array}{c}\text { Group } \\
\text { A }\end{array}$ & $\begin{array}{c}\text { If Group } \\
\text { A } \\
\text { receives } \\
\text { reward }\end{array}$ & $\begin{array}{c}\text { Allocation } \\
\text { to the } \\
\text { individual } \\
\text { account }\end{array}$ & $\begin{array}{c}\text { Allocation } \\
\text { to the group } \\
\text { account }\end{array}$ \\
\hline Type 1 & 60 & 40 & $\mathbf{2 0}$ \\
Type 2 & 30 & 45 & $\mathbf{1 5}$ \\
Type 3 & 30 & 50 & $\mathbf{1 0}$ \\
\hline Total & 120 & 135 & $\mathbf{4 5}$ \\
\hline
\end{tabular}

\begin{tabular}{|l|c|c|c|}
\hline Group B & $\begin{array}{c}\text { If Group } \\
\text { B } \\
\text { receives } \\
\text { reward }\end{array}$ & $\begin{array}{c}\text { Allocation } \\
\text { to the } \\
\text { individual } \\
\text { account }\end{array}$ & $\begin{array}{c}\text { Allocation } \\
\text { to the group } \\
\text { account }\end{array}$ \\
\hline Type 1 & 60 & 50 & $\mathbf{1 0}$ \\
Type 2 & 30 & 60 & $\mathbf{0}$ \\
Type 3 & 30 & 55 & $\mathbf{5}$ \\
\hline Total & 120 & 165 & $\mathbf{1 5}$ \\
\hline
\end{tabular}

Group A members have allocated total of $\mathbf{4 5}$ francs to the group account while group B members only $\mathbf{1 5}$ francs. Thus, the computer will place 45 red tokens and 15 blue tokens into the bingo cage (60 tokens total). Then the compute will randomly draw one token out of the bingo cage. You can see that since group A has contributed more it has higher chance of receiving the reward (45 out of 60 times group A will receive the reward). Group B has lower chance of receiving the reward (15 out of $\mathbf{6 0}$ times group B will receive the reward).

5) After all contributions are made, the computer makes a random draw. Each member of the group that receives the reward will receive the reward according to his or her type. Not all types receive the same reward. For example, if you are type $\mathbf{1}$ in group $\mathbf{A}$ and your group received the reward, you earn $\mathbf{6 0}$ francs from group account. As mentioned earlier, at each period your group as well as your type will be changed. Sometimes you will be a member of group A, sometimes a member of group B. Sometimes you will be type 1 , sometimes type 2 or 3 .

\section{Example 2. Total Earnings}

This example illustrates the calculation of earnings. In Example 1, group A had 45 francs while group B had 15 francs in the group account. Let's say the computer made a random draw and group A received the reward. Thus, all the members of group A receive the reward according to their types from the group account plus they also receive earnings from the individual account. All members of group B receive earnings only from the individual account, since group B did not receive the reward. The calculation of the total earnings is shown in Table 2 below.

Table 2 - Calculation of earning for all types in group $A$ and $B$

\begin{tabular}{|l|c|c|c|c|c|c|c|}
\hline Group A & $\begin{array}{c}\text { Earnings } \\
\text { from } \\
\text { group } \\
\text { account }\end{array}$ & $\begin{array}{c}\text { Earnings } \\
\text { from } \\
\text { individual } \\
\text { account }\end{array}$ & $\begin{array}{c}\text { Total } \\
\text { earnings }\end{array}$ \\
\hline Type 1 & $\mathbf{6 0}$ & $\mathbf{4 0}$ & $60+40=100$ \\
Type 2 & $\mathbf{3 0}$ & $\mathbf{4 5}$ & $\begin{array}{c}30+45=75 \\
\text { Type 3 }\end{array}$ & $\mathbf{3 0}$ & $\mathbf{5 0}$ & $30+50=80$ \\
\hline Total & $\mathbf{1 2 0}$ & $\mathbf{1 3 5}$ & 255 \\
\hline
\end{tabular}

At the end of each period, the total number of francs in the two groups' accounts, group which received the reward, earnings from individual and group accounts, and total earnings for the period are reported on the outcome screen as shown below. Please record your results for the period on your record sheet under the appropriate heading. 


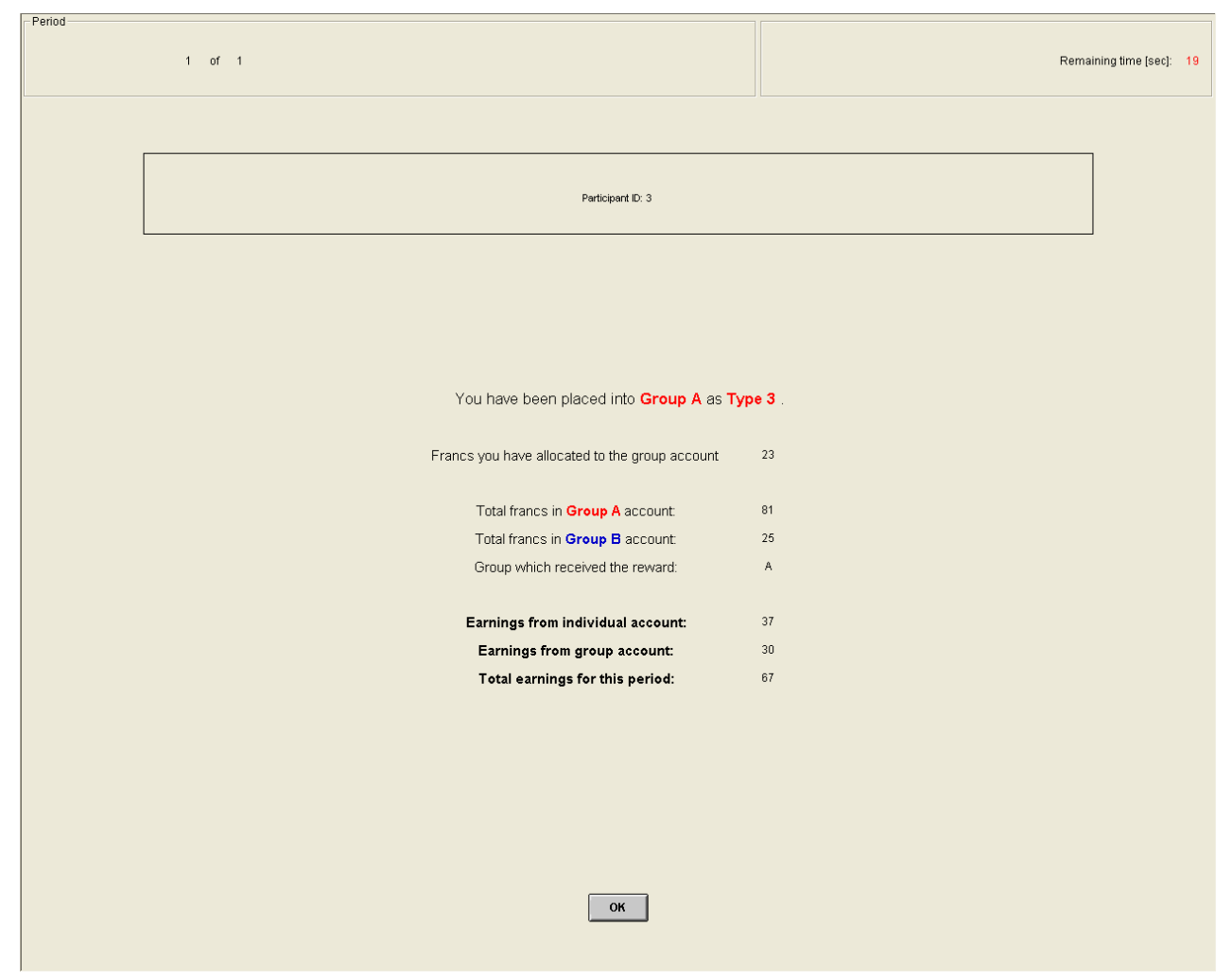

\section{IMPORTANT NOTES}

You will not be told which of the participants in this room are assigned to which group and to which type. At the beginning of each period your group as well as your type will be randomly changed. A group can never guarantee itself the reward. However, by increasing your contribution, you can increase your group's chance of receiving the reward.

At the end of the experiment we will randomly choose $\mathbf{5}$ of the $\mathbf{3 0}$ periods for actual payment in Part $\mathbf{2}$ using a bingo cage. You will sum the total earnings for these 5 periods and convert them to a U.S. dollar payment.

\section{Are there any questions?}

\section{INSTRUCTIONS FOR PART 3}

The third part of the experiment consists of $\mathbf{3 0}$ decision-making periods. The rules for part $\mathbf{3}$ are exactly the same as the rules for part $\mathbf{2}$. The only difference is that in part 3 the rewards for different types in group A and B are different than in part 2:

\begin{tabular}{|l|c|}
\hline \multicolumn{1}{|c|}{ Group A } & Reward \\
\hline Type 1 & 90 \\
Type 2 & 15 \\
Type 3 3 & 15 \\
\hline Total & 120 \\
\hline
\end{tabular}

\begin{tabular}{|l|c|}
\hline \multicolumn{1}{|c|}{ Group B } & Reward \\
\hline Type 1 & 60 \\
Type 2 & 30 \\
Type 3 & 30 \\
\hline Total & 120 \\
\hline
\end{tabular}

\section{IMPORTANT NOTES}

You will not be told which of the participants in this room are assigned to which group and to which type. At the beginning of each period your group as well as your type will be randomly changed. A group can never guarantee itself the reward. However, by increasing your contribution, you can increase your group's chance of receiving the reward.

At the end of the experiment we will randomly choose $\mathbf{5}$ of the $\mathbf{3 0}$ periods for actual payment in Part $\mathbf{3}$ using a bingo cage. You will sum the total earnings for these 5 periods and convert them to a U.S. dollar payment.

Are there any questions? 


\section{2}

\section{Economic Science Institute Working Papers}

12-01 Kimbrough, E. and Sheremeta, R. Side-Payments and the Costs of Conflict. 2011

11-18 Munro, D. and Rassenti, S. Combinatorial Clock Auctions: Price Direction and Performance.

11-17 Schniter, E., Sheremeta, R., and Sznycer, D. Restoring Damaged Trust with Promises, Atonement and Apology.

11-16 Brañas-Garza, P., and Proestakis, A. Self-discrimination: A field experiment on obesity.

11-15 Brañas-Garza, P., Bucheli, M., Paz Espinosa, M., García-Muñoz, T. Moral cleansing and moral licenses: experimental evidence.

11-14 Caginalp, G., Porter, D., and Hao, L. Asset Market Reactions to News: An Experimental Study.

11-13 Porter, D., Rassenti, S. and Smith, V. The Effect of Bidding Information in Ascending Auctions.

11-12 Schniter, E., Sheremeta, R. and Shields, T. Conflicted Minds: Recalibrational Emotions Following Trust-based Interaction.

11-11 Pedro Rey-Biel, P., Sheremeta, R. and Uler, N. (Bad) Luck or (Lack of) Effort?: Comparing Social Sharing Norms between US and Europe.

11-10 Deck, C., Porter, D., Smith, V. Double Bubbles in Assets Markets with Multiple Generations.

11-09 Kimbrough, E., Sheremeta, R., and Shields, T. Resolving Conflicts by a Random Device.

11-08 Brañas-Garza, P., García-Muñoz, T., and Hernan, R. Cognitive effort in the Beauty Contest Game.

11-07 Grether, D., Porter, D., and Shum, M. Intimidation or Impatience? Jump Bidding in On-line Ascending Automobile Auctions.

11-06 Rietz, T., Schniter, E., Sheremeta, R., and Shields, T. Trust, Reciprocity and Rules.

11-05 Corgnet, B., Hernan-Gonzalez, R., and Rassenti, S. Real Effort, Real Leisure and Real-time Supervision: Incentives and Peer Pressure in Virtual Organizations.

11-04 Corgnet, B. and Hernán-González R. Don’t Ask Me If You Will Not Listen: The Dilemma of 
Participative Decision Making.

11-03 Rietz, T., Sheremeta, R., Shields, T., Smith, V. Transparency, Efficiency and the Distribution of Economic Welfare in Pass-Through Investment Trust Games.

11-02 Corgnet, B., Kujal, P. and Porter, D. The Effect of Reliability, Content and Timing of Public Announcements on Asset Trading Behavior.

11-01 Corgnet, B., Kujal, P. and Porter, D. Reaction to Public Information in Markets: How Much Does Ambiguity Matter?

2010

10-23 Sheremeta, R. Perfect-Substitutes, Best-Shot, and Weakest-Link Contests between Groups.

10-22 Mago, S., Sheremeta, R., and Yates, A. Best-of-Three Contests: Experimental Evidence.

10-21 Kimbrough, E. and Sheremeta, R. Make Him an Offer He Can't Refuse: Avoiding Conflicts Through Side Payments.

10-20 Savikhim, A. and Sheremeta, R. Visibility of Contributions and Cost of Inflation: An Experiment on Public Goods.

10-19 Sheremeta, R. and Shields, T. Do Investors Trust or Simply Gamble?

10-18 Deck, C. and Sheremeta, R. Fight or Flight? Defending Against Sequential Attacks in the Game of Siege.

10-17 Deck, C., Lin, S. and Porter, D. Affecting Policy by Manipulating Prediction Markets:

Experimental Evidence.

10-16 Deck, C. and Kimbrough, E. Can Markets Save Lives? An Experimental Investigation of a Market for Organ Donations.

10-15 Deck, C., Lee, J. and Reyes, J. Personality and the Consistency of Risk Taking Behavior: Experimental Evidence.

10-14 Deck, C. and Nikiforakis, N. Perfect and Imperfect Real-Time Monitoring in a Minimum-Effort Game. 
10-13 Deck, C. and Gu, J. Price Increasing Competition? Experimental Evidence.

10-12 Kovenock, D., Roberson, B.,and Sheremeta, R. The Attack and Defense of Weakest-Link Networks.

10-11 Wilson, B., Jaworski, T., Schurter, K. and Smyth, A. An Experimental Economic History of Whalers’ Rules of Capture.

10-10 DeScioli, P. and Wilson, B. Mine and Thine: The Territorial Foundations of Human Property.

10-09 Cason, T., Masters, W. and Sheremeta, R. Entry into Winner-Take-All and Proportional-Prize Contests: An Experimental Study.

10-08 Savikhin, A. and Sheremeta, R. Simultaneous Decision-Making in Competitive and Cooperative Environments.

10-07 Chowdhury, S. and Sheremeta, R. A generalized Tullock contest.

10-06 Chowdhury, S. and Sheremeta, R. The Equivalence of Contests.

10-05 Shields, T. Do Analysts Tell the Truth? Do Shareholders Listen? An Experimental Study of Analysts' Forecasts and Shareholder Reaction.

10-04 Lin, S. and Rassenti, S. Are Under- and Over-reaction the Same Matter? A Price Inertia based Account.

10-03 Lin, S. Gradual Information Diffusion and Asset Price Momentum.

10-02 Gjerstad, S. and Smith, V. Household expenditure cycles and economic cycles, 1920 - 2010.

10-01 Dickhaut, J., Lin, S., Porter, D. and Smith, V. Durability, Re-trading and Market Performance. 2009

09-11 Hazlett, T., Porter, D., Smith, V. Radio Spectrum and the Disruptive Clarity OF Ronald Coase.

09-10 Sheremeta, R. Expenditures and Information Disclosure in Two-Stage Political Contests.

09-09 Sheremeta, R. and Zhang, J. Can Groups Solve the Problem of Over-Bidding in Contests?

09-08 Sheremeta, R. and Zhang, J. Multi-Level Trust Game with "Insider" Communication.

09-07 Price, C. and Sheremeta, R. Endowment Effects in Contests. 
09-06 Cason, T., Savikhin, A. and Sheremeta, R. Cooperation Spillovers in Coordination Games.

09-05 Sheremeta, R. Contest Design: An Experimental Investigation.

09-04 Sheremeta, R. Experimental Comparison of Multi-Stage and One-Stage Contests.

09-03 Smith, A., Skarbek, D., and Wilson, B. Anarchy, Groups, and Conflict: An Experiment on the Emergence of Protective Associations.

09-02 Jaworski, T. and Wilson, B. Go West Young Man: Self-selection and Endogenous Property Rights.

09-01 Gjerstad, S. Housing Market Price Tier Movements in an Expansion and Collapse.

2008

08-09 Dickhaut, J., Houser, D., Aimone, J., Tila, D. and Johnson, C. High Stakes Behavior with Low Payoffs: Inducing Preferences with Holt-Laury Gambles.

08-08 Stecher, J., Shields, T. and Dickhaut, J. Generating Ambiguity in the Laboratory.

08-07 Stecher, J., Lunawat, R., Pronin, K. and Dickhaut, J. Decision Making and Trade without Probabilities.

08-06 Dickhaut, J., Lungu, O., Smith, V., Xin, B. and Rustichini, A. A Neuronal Mechanism of Choice.

08-05 Anctil, R., Dickhaut, J., Johnson, K., and Kanodia, C. Does Information Transparency

Decrease Coordination Failure?

08-04 Tila, D. and Porter, D. Group Prediction in Information Markets With and Without Trading Information and Price Manipulation Incentives.

08-03 Thomas, C. and Wilson, B. Horizontal Product Differentiation in Auctions and Multilateral Negotiations.

08-02 Oprea, R., Wilson, B. and Zillante, A. War of Attrition: Evidence from a Laboratory Experiment on Market Exit.

08-01 Oprea, R., Porter, D., Hibbert, C., Hanson, R. and Tila, D. Can Manipulators Mislead Prediction Market Observers? 